\title{
Effect of Genetic Drift versus Natural Selection on Clutch Traits in Two Populations of the Nigerian Local Chickens
}

\author{
Gwaza DS*, Dim NI and Momoh OM \\ Department of Animal Breeding and Physiology, University of Agriculture, Nigeria \\ *Corresponding author: GwazaDS, Department of Animal Breeding and Physiology, University of Agriculture, Makurdi, Nigeria
}

Submission: January 19, 2018; Published: July 06, 2018

\begin{abstract}
The study was carried out at Akpehe poultry farm, Makurdi,on the Tiv and the Fulani Nigerian local chicken ecotypes.The variability on clutch traits were estimated on 540 hens produced from the mating of 40 hens and 4 sires each for the Tiv and the Fulani local chicken ecotypes, randomly selected from rural populations. The hens were housed singly and hand mated. Daily egg production was recorded individually. The data was organized according to clutch size, clutch number, pause number and pause length. SAS procedure was used to analyze the variability on clutch traits within and between the ecotypes.Clutch size has the highest variability within the ecotype. Between the ecotypes, the Tiv ecotype showed higher variability in clutch traits than the Fulani ecotype. The higher variability in the Tiv ecotype was related to the large population of single inter breeding flock which renders genetic drift insignificant. The small reproductive population often left when the Fulani women disposed large numbers of matured birds from their flock when preparing for new settlements thereby accelerating genetic drift. This had driven the population of the Fulani ecotype towards genetic uniformity in clutch traits by reducing genetic variation overtime. The genetic diversity of the Fulani ecotype in clutch traits that could be used for current and future adaptation is been threatened.
\end{abstract}

Keywords: Clutch-traits; Fulani;Genetic-drift; Tiv; Variability

\section{Introduction}

In natural populations, genetic drifts and natural selection do not act in isolation; both forces are always at play. The degree to which alleles are affected by drift or selection varies according to the population size, and the magnitude of drift on allelic frequencies per generation is larger in small populations [1]. Genetic drifts can overpower natural selection when the allele frequency is very small even in large populations [2]. Genetic drifts acts upon the genetic frequencies within a population without regard to their phenotypic effects presenting the sampled alleles for natural selection. It favors the spread of alleles where phenotypic effects increase survival and or reproduction of their carriers [3]. The Nigerian local chickens have not being characterized into breeds. Their genetic resources, abundance and variation are dictated by cultural practices and preferences through unconscious, non-directional, counter- selection, settlement patterns and local environment [4]. There are numerous ethnic groups with diverse cultural practices in Nigeria. The Fulani ethnic group is nomadic cattle rearers while their females keep local chickens. The Tiv ethnic group is sedentary peasant crop farmers who practiced communal settlement. While the cultural practices of the Fulani requires their women to reduce the population of their local chickens for easy movement to create new ones at subsequent settlements. The communal sedentary settlement pattern of the Tiv ethnic group allows the existence of single interbreeding flock of local chickens. The settlement patterns and population sizes involved will influence the distribution of sampled alleles between populations through random sampling [5]. The Nigerian local chicken populations under rural farmers are more or less under natural influence. Some of these farmers keep small population sizes in isolated areas precluding the introduction of new genes from other populations. Furthermore, these farmers most often dispose matured birds for economic reasons or in preparation for a new settlement thereby accelerating genetic drifts through random sampling. The aim of this study was to provide information on the variability of clutch traits as affected by genetic drift through random sampling and selection in the Nigerian local chickens in relation to the life style of their keepers.

\section{Material and Methods}

The study was carried out at Akpehe poultry farm, Makurdi. Akpehe poultry farm is located on latitude $7^{0} 4^{1} \mathrm{~N}$ and longitude 83 ${ }^{0} 1^{1} \mathrm{E}$ (Microsoft Encarta, 2008). Makurdi is warm with temperature range of $17.3{ }^{\circ} \mathrm{C}-35.6{ }^{\circ} \mathrm{C}$. Rainfall is between $508 \mathrm{~mm}-1016 \mathrm{~mm}$ [6]. 
The relative humidity ranged from 47 to 85 percent [7]. The birds were housed in dwarf wall wire mesh screened pens and the house was roofed with corrugated roofing sheets. The birds were housed individually. They were reared on deep litter management system. The birds were given anti stress on arrival and also on the following day, were vaccinated against Newcastle disease (Lasota). They were deworm and dusted for ectoparasites and allowed to acclimatize for four weeks. They were fed a formulated diet containing 18 percent crude protein. The birds were fed in the morning and evening and water was provided ad labium.

About 40 hens and 4 sires each of the Fulani and Tiv chickens ecotype selected from rural populations were used. The hens were housed singly and hand-mated. Eggs were collected from 540 hens produced from 80 dams by 8 sires in the ratio of 10 dams per sire for each ecotype. Daily egg production was recorded individually. Clutch number (CLN), Clutch size (CLS), Pause number (PAUN) and Pause length (PAUL) were calculated. Clutch size was estimated as the number of eggs laid consecutively. At least one-day-break in lay was taken as the end of a clutch and recorded as clutch number and Pause number. The number of day or days before the resumption of lay was estimated as the Pause length.

\section{Statistical Analysis}

The data was analyzed by SAS (1996). The variance and coefficient of variability were also obtained for all the clutch traits within and between the ecotypes.

\section{Results}

Table 1: Genetic variability within the Fulani ecotype on clutch trait. Clun clutch number, clus, clutch size paun pause number and paul pause length. SE standard error, SD standard deviation $\mathrm{CV}$ coefficient of variation.

\begin{tabular}{|c|c|c|c|c|c|}
\hline Clutch Traits & Mean & SE & SD & Variance & CV(\%) \\
\hline CLUN & 2.795 & 0.149 & 1.269 & 1.61 & 45.4 \\
\hline CLUS & 9.63 & 0.401 & 3.426 & 10.736 & 35.57 \\
\hline PAUN & 3.233 & 0.119 & 1.021 & 1.042 & 31.58 \\
\hline PAUL & 2.589 & 0.112 & 0.955 & 0.912 & 36.89 \\
\hline
\end{tabular}

Table 2: Genetic variability between the ecotypes on clutch traits. Clun clutch number, clus, clutch size paun pause number and paul pause length. SE standard error, SD standard deviation CV coefficient of variation.

\begin{tabular}{|c|c|c|c|c|c|c|}
\hline $\begin{array}{c}\text { Clutch } \\
\text { Trait }\end{array}$ & $\begin{array}{c}\text { Eco- } \\
\text { type }\end{array}$ & Mean & SE & SD & $\begin{array}{c}\text { Vari- } \\
\text { ance }\end{array}$ & CV (\%) \\
\hline \multirow{2}{*}{ CLUN } & Fulani & 2.795 & 0.149 & 1.269 & 1.61 & 45.4 \\
\cline { 2 - 7 } & Tiv & 2.019 & 0.085 & 0.61 & 0.372 & 30.21 \\
\hline \multirow{2}{*}{ CLUS } & Fulani & 9.63 & 0.401 & 2.426 & 10.736 & 35.57 \\
\cline { 2 - 7 } & Tiv & 7.212 & 0.444 & 3.201 & 11.248 & 44.39 \\
\hline \multirow{2}{*}{ PAUN } & Fulani & 3.233 & 0.119 & 1.021 & 1.042 & 31.58 \\
\cline { 2 - 7 } & Tiv & 3.538 & 0.197 & 1.421 & 2.018 & 40.15 \\
\hline \multirow{2}{*}{ PAUL } & Fulani & 2.589 & 0.112 & 0.955 & 0.912 & 36.89 \\
\cline { 2 - 7 } & Tiv & 2.615 & 0.14 & 1.013 & 1.026 & 38.72 \\
\hline
\end{tabular}

The Fulani ecotype chicken showed lower variability in all the clutch traits than Tiv ecotype chicken except in clutch number (Table 1). The highest genetic variability was recorded on clutch size (10.736) followed by clutch number (1.610). Pause number (1.021) and pause length $(0.912)$ were less varied (Table 2). Between the ecotypes, the Fulani ecotype showed lower variability in all the clutch traits than the Tiv ecotypes except on clutch number (Table 2). Clutch size had the highest genetic variability (11.248). Pause number and length (2.018 and 1.026) followed respectively. Clutch number least varied (0.372) among the Tiv ecotypes (Table 3).

Table 3: Genetic variability within the Tiv ecotype on clutch traits. Clun, clutch number, clus, clutch size, paun pause number, and paul pause length. SE standard error, SD standard deviation CV coefficient of variation.

\begin{tabular}{|c|c|c|c|c|c|}
\hline Clutch Traits & Mean & SE & SD & Variance & CV (\%) \\
\hline CLUN & 2.019 & 0.085 & 0.61 & 0.3722 & 30.21 \\
\hline CLUS & 7.212 & 0.444 & 3.201 & 11.248 & 44.39 \\
\hline PAUN & 3.538 & 0.197 & 1.421 & 2.018 & 40.15 \\
\hline PAUL & 2.615 & 0.14 & 1.013 & & 38.72 \\
\hline
\end{tabular}

\section{Discussion}

\section{Genetic variability within the fulani ecotype}

The highest variability observed on clutch size of the Fulani ecotype indicated greater genetic potential and variation between the birds in this trait $[8,9]$. This also showed that the birds within this ecotype were highly adapted on these traits. The low variability in pause length and number, clutch number and length could mean low adaptation of the birds in these traits such that they were restricted by the environmental challenges. The high variability observed on the clutch size in this study was advantageous; because this gives room for efficient selection and breeding to improve clutch size.

\section{Genetic variability within the Tiv ecotype}

Within the Tiv ecotype, the highest variation in clutch size could be due to the reason ascribed for that in the Fulani ecotype. The values in the total variance in pause number and pause length were due to better adaptation of this ecotype, and that it tolerated environmental restrictions better in this trait than the Fulani ecotype. The birds in the Tiv ecotype however seemed to have low genetic potential in clutch number.

\section{Establishing new values for allele distribution and drift by random sampling and fluctuations}

The consistently lowered standard deviation, variance and coefficient of variation due to clutch traits of the Fulani ecotype compared to the Tiv ecotype indicated that there was lower genetic variability in these traits among the Fulani birds. This was possible because, small flock of the Fulani ecotypes are restricted in isolated areas precluding the introduction of genes from other populations. Furthermore, the Fulani women who are the custodian of these birds most often disposed off matured birds while preparing for movement to new settlement. The reproductive population left is 
often small and the alleles in the offspring population would deviate from that of the parental population due to random sampling [10]. When random fluctuations resulted in a change of the allele frequency from the parent generation to the offspring generation, that deviation establishes new expected values for the allele distributions in the next generation to follow thereby initiating allelic drift $[11,12]$. The frequencies of more alleles in the population will be affected because random sampling can cause an existing allele to disappear or decline, but not replaced, and because random declined in allele frequency influence expected allele distributions for the next generation, genetic drift drives a population towards genetic uniformity by eliminating genetic variation overtime [13]. This is also likely to be accelerated by inbreeding. It did appear that genetic drift had reduced the variability in clutch traits of the Fulani ecotype over time.

Random sampling can remove, decline or increases allele frequency which dictates the expected allele distributions for the next generation depending on the population size; since the magnitude of genetic drift on allelic frequencies per generation is larger in small populations. Thus genetic drift, though random and directionless process acts to eliminate genetic variation overtime. Relating the above to the isolated small flock size scattered among the herding Fulani's, it did appear that genetic drift had driven the populations of the Fulani ecotype towards uniformity in clutch traits. Alleles that could be used for current and future adaptation for future environmental changes are been lost due to sampling error. This is a treat to the genetic diversity of this ecotype to provide options and opportunities for the future [14].

The high standard deviation, variance and the coefficient of variation among the clutch traits of the Tiv ecotype was also expected. This was because; the Tiv rural farmers that reared these birds lived together as a community, such that the flocks of each farmer do not exist in isolation. A collection of each farmer flock for all the farmers in the community exists as a large population of single interbreeding flock. The large population size renders the effect of genetic drift insignificant and exposes higher frequencies of allele to natural selection for better adaptation. This was why the Tiv ecotype was better adapted with higher variability on clutch traits than the Fulani ecotype. future adaptation to environmental changes. It is recommended that a further study be conducted in this area to determine the "time to fixation or loss" of alleles in this population to be able to determine the reproduction population size to reduce genetic drift.

\section{References}

1. Small KS, Brudno M, Hill MM, Sidow A (2007) Extreme genomic variation in a natural population. Proc Natl Acad Sci U S A 104(13): 5698-703.

2. Harlt D (2006) Principles of population genetics. Sinauer Associates, $\left(4^{\text {th }}\right.$ edn), USA, p. 102.

3. Caralli SLL, Menozzi P, Piazza A (1996) The history and geography of human. Princeton University Press, USA, p. 518.

4. Gwaza DS, Dim NI, Momoh OM (2012) Effect of genetic drift versus natural Selection on clutch traits in two populations of the Nigerian local chickens. In: Bitto II, Kaankuka FG, Attah S (Eds.), Sustainable animal production for national security and poverty alleviation, University of Agriculture, India, pp. 43-48.

5. Gwaza DS, Winfred MI, Samuel SC (2015) Genetic distance between populations of the Tiv local chickens in the derived guinea savanah zone of Nigeria. Journal of Agriculture and Veterinary Science 8(2): 103-106.

6. BSN (Benue State of Nigeria) (1982) The government and people of Benue State. Benue State Gazette. Benue State Ministry of Information. Onaiviprestery Press, Nigeria, pp. 1-9.

7. TAC (2002) Makurdi weather elements records. Tactical Air Command Makurdi, Metrological Station, Nigeria.

8. Akbas Y, Unver Y, Oguz I, Altan O (2002) Estimate of genetic parameters for clutch traits in laying hens. $7^{\text {th }}$ world congress on genetic applied to livestock production, Montpellier, France, pp. 19-23.

9. Kieu ML, Miyoshi S, Mitsuyoshi S (1996) Heritability estimate of some clutch traits in the laying hen. Japanese poultry science 33 (1): 23-28.

10. Kimura M, Ohta T (2001) Theoretical aspects of population genetics. Princeton University Press, USA, 4: 232.

11. Wen H, Dan G, Hsiung WHI (1991) Fundamentals of molecular Evolution. Sinauer Associates, USA, p. 33.

12. William KP, David M, David ES, Heller CH (2006) Life: the science of biology ii evolution, diversity and ecology. San Francisco WH Freeman, USA, p. 389.

13. Hsiung LW (1991) Fundamentals of molecular evolution. Sinauer Associates SAS (1996) User's Guild, SAS Institute Inc, USA, p. 29.

14. Dev RAK (2010) Broiler breeding strategies to 2020. In: Sasidhar PVK (Ed.), Poultry Research Priorities to 2020. Proceedings of National Seminar, Izatnagar, India.

\section{Conclusion}

Genetic drift is a treat to the genetic diversity of the Fulani ecotype on clutch traits that could be use for improvement and

Creative Commons Attribution 4.0 International License

For possible submissions Click Here

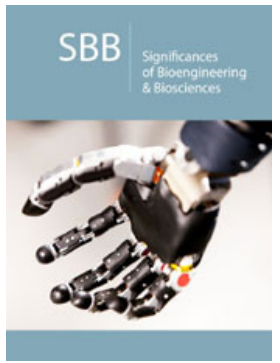

Significances of Bioengineering \& Biosciences

\section{Benefits of Publishing with us}

- High-level peer review and editorial services

- Freely accessible online immediately upon publication

- Authors retain the copyright to their work

- Licensing it under a Creative Commons license

- Visibility through different online platforms 